\title{
Intermolecular Interaction of Glycyrrhizin with Cholesterol
}

\author{
L. A. Yakovishin ${ }^{\mathrm{a}^{*}}$, V.I. Grishkovets ${ }^{\mathrm{b}}$ \\ ${ }^{a}$ Sevastopol State University, 33 University Str., \\ Sevastopol, 299053, Russia \\ ${ }^{b}$ V.I. Vernadsky Crimean Federal University, \\ 4 Vernadsky Ave., Simferopol, 295007, Russia \\ *email: chemsevntu@rambler.ru
}

Abstract. The 1:1 molecular complex of licorice triterpene glycoside glycyrrhizic acid (in the form of monoammonium salt) with cholesterol was obtained in $80 \%$ aqueous isopropyl alcohol for the first time. The complexation was studied by ${ }^{13} \mathrm{C} \mathrm{NMR}$, UV, and ATR IR-Fourier spectroscopy. The hydrogen bonds and hydrophobic interactions are formed in the molecular complex.

Keywords: triterpene glycosides; licorice; glycyrrhizin; glycyrrhizic acid; cholesterol; molecular complex

Received: 27.10.2020. Accepted: 09.12.2020. Published:30.12.2020.

(c) Yakovishin L. A., Grishkovets V. I., 2020

\section{Introduction}

Glycyrrhizin (glycyrrhizic acid, 3-O- $\beta$-D-glucuronopyranosyl- $(1 \rightarrow 2)$ $\mathrm{O}-\beta$-D-glucuronopyranoside of $18 \beta$-glycyrrhetinic acid, GA; Fig. 1) is the dominant triterpene saponin from licorice roots Glycyrrhiza glabra L. and Glycyrrhiza uralensis Fisch. (Fabaceae) [1,2]. GA has anti-inflammatory, antioxidative, antiviral, anticancer, hypocholesterolemic, and hepatoprotective properties [1-3]. The most important derivative of GA is its monoammonium salt (monoammonium glycyrrhizinate, glycyram, GC; Fig. 1). GC is used as an anti-inflammatory, hepatoprotective, antiallergic, mineralocorticoid, and antitussive drug [2-4].
Some biological properties of saponins explain their molecular complexation with sterols [1, 2, 5-7]. GA increases permeability and reduces the elastic modulus of cell membranes [8]. On the other hand, recent spectrophotometric titration did not confirm the complexation of GC with cholesterol (Chol; Fig. 1) and 1,2-dipalmitoylphosphatidylcholine [9]. The authors of this paper have been suggested that the presence of 11-oxo group in the GC aglycone part prevents its complexation.

In order to consider the possibility of complexation of GC with Chol in various media, we studied their intermolecular interaction in aqueous isopropyl alcohol by NMR, IR, and UV spectroscopy.

\section{Experimental}

GC (purity $\geq 95 \%$ by HPLC) was purchased from Calbiochem. Chol and other chemicals in the highest grade of purity were obtained from Sigma-Aldrich. 
The complex of Chol with GC was preparatively obtained by liquid-phase method. For this purpose, $1 \mathrm{mmol}$ of the substances was mixed with $50 \mathrm{~mL}$ of $80 \%$ aqueous isopropyl alcohol (v/v). The obtained mixture was incubated at $50{ }^{\circ} \mathrm{C}$ for $1.5 \mathrm{~h}$ with continuous stirring. The organic solvent was removed by vacuuming.

UV spectra of Chol solutions ( 0.50 . $\cdot 10^{-4} \mathrm{M}=$ const) with different concentrations of GC $\left(0,0.125 \cdot 10^{-4}, 0.25 \cdot 10^{-4}\right.$, $0.50 \cdot 10^{-4}, 1.0 \cdot 10^{-4} \mathrm{M}$ ) were recorded on a LEKI SS2110UV spectrophotometer using a quartz cuvette $(l=1 \mathrm{~cm})$ at $25^{\circ} \mathrm{C}$.

The IR spectra were recorded on a Simex FT-801 IR-Fourier spectrometer in the $4000-550 \mathrm{~cm}^{-1}$ region (spectral resolution $4 \mathrm{~cm}^{-1}$; 50 scans) using the universal optical attenuated total reflection (ATR) accessory with diamond crystal plate.

IR spectrum of GC $\left(v, \mathrm{~cm}^{-1}\right): 3197(\mathrm{OH}$, $\mathrm{NH}), 2928(\mathrm{CH}), 2907(\mathrm{CH}), 2868(\mathrm{CH})$, $1719(\mathrm{C}=\mathrm{O}), 1708(\mathrm{C}=\mathrm{O}), 1641(\mathrm{C}(11)=\mathrm{O}$, $\mathrm{C}=\mathrm{C}), 1587\left(\mathrm{COO}^{-}\right), 1451(\mathrm{CH}), 1425$ $\left(\mathrm{NH}_{4}^{+}\right), 1416\left(\mathrm{COO}^{-}\right), 1387(\mathrm{CH}), 1357$ $(\mathrm{CH}), 1318(\mathrm{CH}), 1260(\mathrm{CH}), 1211(\mathrm{CH})$, 1162 (C-O-C, C-OH), 1037 (C-O-C, C$\mathrm{OH}), 980(=\mathrm{CH}), 946(\mathrm{CH}), 918$ (monosaccharide ring), $880(\mathrm{CH}), 818(\mathrm{CH}), 793$ $(\mathrm{CH}), 694(\mathrm{CH}), 687(\mathrm{CH}), 679(=\mathrm{CH})$, $663(\mathrm{OH})$.
IR spectrum of Chol $\left(v, \mathrm{~cm}^{-1}\right): 3403$ $(\mathrm{OH}), 3337(\mathrm{OH}), 2929(\mathrm{CH}), 2899(\mathrm{CH})$, $2865(\mathrm{CH}), 2848(\mathrm{CH}), 1672(\mathrm{C}=\mathrm{C}), 1460$ $(\mathrm{CH}), 1434(\mathrm{CH}), 1377(\mathrm{CH}), 1364(\mathrm{CH})$, $1341(\mathrm{CH}), 1333(\mathrm{CH}), 1318(\mathrm{CH}), 1275$ $(\mathrm{CH}), 1268(\mathrm{CH}), 1253(\mathrm{CH}), 1234(\mathrm{CH})$, $1220(\mathrm{CH}), 1190(\mathrm{CH}), 1169(\mathrm{C}-\mathrm{OH}), 1132$ $(\mathrm{C}-\mathrm{OH}), 1106(\mathrm{C}-\mathrm{OH}), 1052(\mathrm{C}-\mathrm{OH})$, $1022(\mathrm{C}-\mathrm{OH}), 986(=\mathrm{CH}), 953(\mathrm{CH}), 925$ (=CH), $881(\mathrm{CH}), 839(\mathrm{C}-\mathrm{C}-\mathrm{C}), 799(\mathrm{CH})$, $738(\mathrm{CH}), 720(\mathrm{CH}), 694(\mathrm{CH}), 687(\mathrm{CH})$, $679(=\mathrm{CH}), 662(\mathrm{OH})$.

IR spectrum of the complex of GC with Chol $\left(v, \mathrm{~cm}^{-1}\right): 3216(\mathrm{OH}, \mathrm{NH}), 2928(\mathrm{CH})$, $2903(\mathrm{CH}), 2863(\mathrm{CH}), 1717(\mathrm{C}=\mathrm{O}), 1698$ $(\mathrm{C}=\mathrm{O}), 1669\left(\mathrm{C}=\mathrm{C}_{\text {Chol }}\right), 1648(\mathrm{C}(11)=\mathrm{O}$, $\left.\mathrm{C}=\mathrm{C}_{\mathrm{GC}}\right), 1586\left(\mathrm{COO}^{-}\right), 1459(\mathrm{CH}), 1450$ $(\mathrm{CH}), 1433(\mathrm{CH}), 1424\left(\mathrm{NH}_{4}^{+}\right), 1418$ $\left(\mathrm{COO}^{-}\right), 1386(\mathrm{CH}), 1379(\mathrm{CH}), 1362$ $(\mathrm{CH}), 1339(\mathrm{CH}), 1316(\mathrm{CH}), 1277(\mathrm{CH})$, $1261(\mathrm{CH}), 1211(\mathrm{CH}), 1163(\mathrm{C}-\mathrm{O}-\mathrm{C}$, $\mathrm{C}-\mathrm{OH}), 1038$ (C-O-C, C-OH), 1030 (C-O-C, C-OH), 978 (=CH), $947(\mathrm{CH})$, 919 (monosaccharide ring, $=\mathrm{CH}$ ), 880 $(\mathrm{CH}), 818(\mathrm{CH}), 795(\mathrm{CH}), 741(\mathrm{CH}), 719$ $(\mathrm{CH}), 692(\mathrm{CH}), 685(\mathrm{CH}), 679(=\mathrm{CH})$, $662(\mathrm{OH})$.

${ }^{13} \mathrm{C}$ NMR spectra were recorded on a Bruker WM-250 spectrometer $(62.9 \mathrm{MHz}$ for ${ }^{13} \mathrm{C}$ ) in $\mathrm{C}_{5} \mathrm{D}_{5} \mathrm{~N}$ at $30^{\circ} \mathrm{C}$. NMR spectra are reported in Tables 1 and 2 .

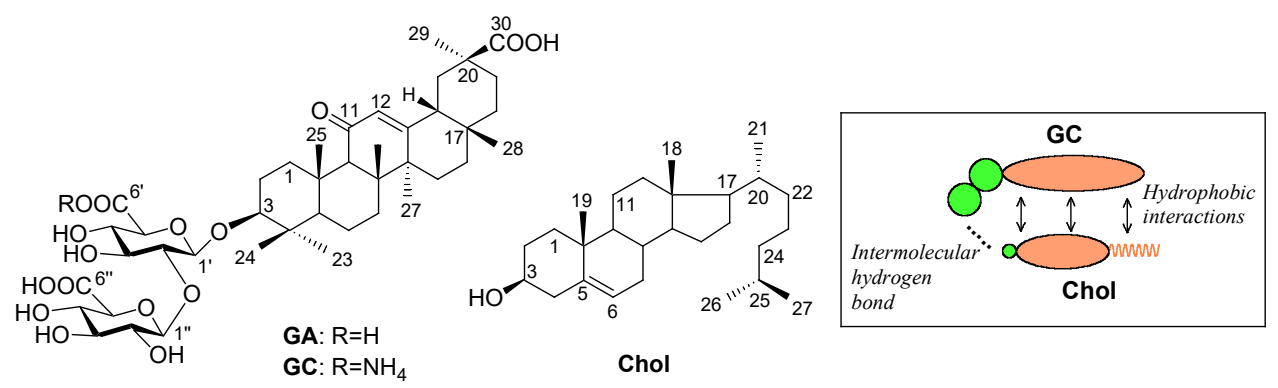

Fig. 1. Chemical structures of GA, GC, Chol and schematic representation of the possible orientation of GC and Chol molecules during their intermolecular interaction 


\section{Results and discussion}

The intermolecular interaction of GC with Chol was studied by UV spectroscopy. As the GC concentration increases (at constant Chol concentration), the optical density of their solutions increases (hyperchromic effect) (Fig. 2). The absorption maximum of the solutions increases (bathochromic shift) from 237 to $250 \mathrm{~nm}$. Similar spectral changes were previously noted for molecular complexes of some triterpene glycosides [10] and cyclodextrins [11].

The complex of Chol with GC was preparatively obtained by liquid-phase method in $80 \%$ aqueous isopropyl alcohol. The potential centers of intermolecular interactions in the molecules are $\mathrm{COOH}$ groups of GC and $\mathrm{OH}$ group of Chol. The lipophilic nature of the aglycone part of GC and sterane system with the hydrocarbon "tails" in Chol may contribute to hydrophobic contacts between them.

The nature of intermolecular interactions in the complex was confirmed by ATR
FT-IR spectroscopy. Upon the formation of complex in the IR spectra for the absorption bands of stretching vibrations of Chol O-H bonds are observed shifts from 3403 and $3337 \mathrm{~cm}^{-1}$ to $3216 \mathrm{~cm}^{-1}$, and for GC - from 3197 to $3216 \mathrm{~cm}^{-1}$. We also found a low-frequency shift of the absorption band of $\mathrm{C}=\mathrm{O}$ bond in one of GC carboxyl groups at $1708 \mathrm{~cm}^{-1}$ by $10 \mathrm{~cm}^{-1}$. Similar shifts of the absorption bands of $\mathrm{C}=\mathrm{O}$ bonds in IR spectra were previously observed during the interaction of ivy triterpene glycosides with Chol [12], as well as during the formation of GA and GC complexes [11]. In addition, the band of stretching vibrations of $\mathrm{C}-\mathrm{O}$ bonds in $\mathrm{C}-\mathrm{OH}$ for $\mathrm{GC}$ at $1037 \mathrm{~cm}^{-1}$ shifts by $-7 \mathrm{~cm}^{-1}$ and for Chol at 1169,1052 , and $1022 \mathrm{~cm}^{-1}-$ by $-6,-14$, and $+8 \mathrm{~cm}^{-1}$, respectively. IR spectroscopic data indicate about the formation of a hydrogen bond between $\mathrm{Chol} \mathrm{OH}$ group and $\mathrm{C}=\mathrm{O}$ group in one of GC carboxyl groups:

$$
\mathrm{C}=\mathrm{O}_{\mathrm{GC}} \cdots \mathrm{H}-\mathrm{O}_{\mathrm{Chol}} \cdot
$$

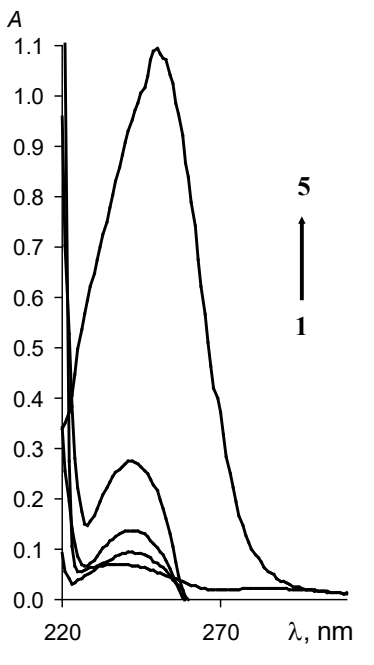

$a$

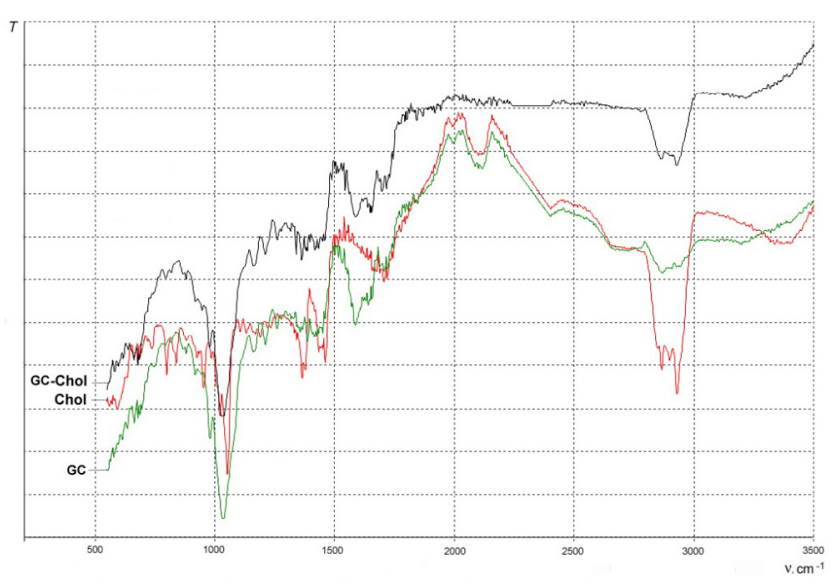

$b$

Fig. 2. UV spectra of Chol solutions $\left(0.50 \cdot 10^{-4} \mathrm{M}=\right.$ const $)$ with different concentrations of GC: $0 \mathrm{M}$ (curve 1 ), $0.125 \cdot 10^{-4}$ (curve 2), $0.25 \cdot 10^{-4}$ (curve 3), $0.50 \cdot 10^{-4}$ (curve 4 ), $1.0 \cdot 10^{-4}$ (curve 5) (a) and ATR FT-IR spectra of GC, Chol, and GC-Chol molecular complex $(b)$ 
${ }^{13} \mathrm{C}$ NMR spectral data for free GC and GC in the molecular complex with $\mathrm{Chol}\left(\delta, \mathrm{ppm}, 0-\mathrm{TMS}, \mathrm{C}_{5} \mathrm{D}_{5} \mathrm{~N}, 30^{\circ} \mathrm{C}\right)$

\begin{tabular}{|c|c|c|c|c|c|c|c|}
\hline 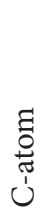 & ن & 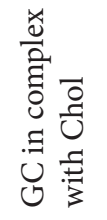 & 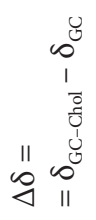 & 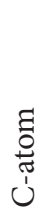 & U & 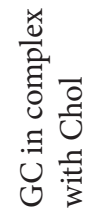 & 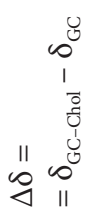 \\
\hline \multicolumn{8}{|c|}{ Aglycone part } \\
\hline 1 & 40.03 & 40.04 & 0.01 & 16 & 26.78 & 26.75 & -0.03 \\
\hline 2 & 26.96 & 26.96 & 0 & 17 & 32.23 & 32.23 & 0 \\
\hline 3 & 89.28 & 89.30 & 0.02 & 18 & 48.81 & 48.82 & 0.01 \\
\hline 4 & 40.14 & 40.15 & 0.01 & 19 & 41.84 & 41.89 & 0.05 \\
\hline 5 & 55.52 & 55.51 & -0.01 & 20 & 44.19 & 44.19 & 0 \\
\hline 6 & 17.66 & 17.68 & 0.02 & 21 & 31.72 & 31.71 & -0.01 \\
\hline 7 & 33.05 & 33.07 & 0.02 & 22 & 38.51 & 38.51 & 0 \\
\hline 8 & 43.55 & 43.58 & 0.03 & 23 & 28.17 & 28.16 & -0.01 \\
\hline 9 & 62.20 & 62.19 & -0.01 & 24 & 16.91 & 16.92 & 0.01 \\
\hline 10 & 37.29 & 37.29 & 0 & 25 & 16.79 & 16.78 & -0.01 \\
\hline 11 & 199.62 & 199.63 & 0.01 & 26 & 18.87 & 18.87 & 0 \\
\hline 12 & 128.75 & 128.75 & 0 & 27 & 23.66 & 23.65 & -0.01 \\
\hline 13 & 169.63 & 169.63 & 0 & 28 & 28.85 & 28.85 & 0 \\
\hline 14 & 45.63 & 45.61 & -0.02 & 29 & 28.85 & 28.85 & 0 \\
\hline 15 & 26.78 & 26.75 & -0.03 & 30 & 179.22 & 179.21 & -0.01 \\
\hline
\end{tabular}

Carbohydrate part

\begin{tabular}{c|c|c|c|c|c|c|c}
\hline \multicolumn{5}{c|}{ GlcUA' $^{\prime}$} & \multicolumn{4}{c}{ GlcUA" $^{\prime \prime}$} \\
\hline $1^{\prime}$ & 105.10 & 105.12 & 0.02 & $1^{\prime \prime}$ & 106.63 & 106.61 & -0.02 \\
\hline $2^{\prime}$ & 82.82 & 82.82 & 0 & $2^{\prime \prime}$ & 76.71 & 76.74 & 0.03 \\
\hline $3^{\prime}$ & 77.15 & 77.16 & 0.01 & $3^{\prime \prime}$ & 77.65 & 77.67 & 0.02 \\
\hline $4^{\prime}$ & 73.45 & 73.47 & 0.02 & $4^{\prime \prime}$ & 73.51 & 73.50 & -0.01 \\
\hline $5^{\prime}$ & 78.02 & 78.00 & -0.02 & $5^{\prime \prime}$ & 78.23 & 78.15 & -0.08 \\
\hline $6^{\prime}$ & 172.92 & 172.94 & 0.02 & $6^{\prime \prime}$ & 174.19 & 174.03 & -0.16 \\
\hline
\end{tabular}

The complexation also causes changes in certain frequencies of absorption of $\mathrm{CH}$ bonds: $2868 \rightarrow 2863 \mathrm{~cm}^{-1}$ and 2907 $\rightarrow 2903 \mathrm{~cm}^{-1}$ (for GC), and also $2899 \rightarrow$ $2903 \mathrm{~cm}^{-1}, 953 \rightarrow 947 \mathrm{~cm}^{-1}$, and $799 \rightarrow$ $795 \mathrm{~cm}^{-1}$ (for Chol). These facts may indicate the presence of hydrophobic contacts between Chol and GC molecules.
The location of GC carboxyl group involved in the interaction with Chol was determined by ${ }^{13} \mathrm{C}$ NMR spectroscopy. The value of the chemical shift of the C-30 atom in the carboxyl group of the aglycone portion of GC remains practically unchanged (Table 1). However, there is a change in the chemical shift of the $C-6^{\prime \prime}$ 
${ }^{13} \mathrm{C}$ NMR spectral data for free $\mathrm{Chol}$ and $\mathrm{Chol}$ in the molecular complex with GC

$\left(\delta, \mathrm{ppm}, 0-\mathrm{TMS}, \mathrm{C}_{5} \mathrm{D}_{5} \mathrm{~N}, 30^{\circ} \mathrm{C}\right)$

\begin{tabular}{|c|c|c|c|c|c|c|c|}
\hline 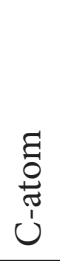 & 응 & 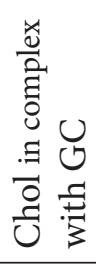 & 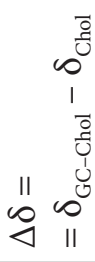 & 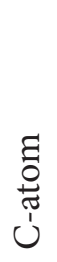 & 훙 & 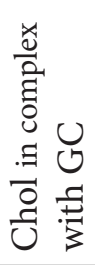 & 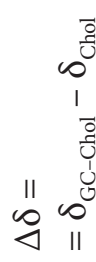 \\
\hline 1 & 37.92 & 37.94 & 0.02 & 15 & 24.59 & 24.62 & 0.03 \\
\hline 2 & 32.71 & 32.71 & 0 & 16 & 28.58 & 28.61 & 0.03 \\
\hline 3 & 71.35 & 71.38 & 0.03 & 17 & 56.49 & 56.52 & 0.03 \\
\hline 4 & 43.59 & 43.58 & -0.01 & 18 & 12.09 & 12.13 & 0.04 \\
\hline 5 & 142.07 & 142.06 & -0.01 & 19 & 19.68 & 19.72 & 0.04 \\
\hline 6 & 121.29 & 121.31 & 0.02 & 20 & 36.11 & 36.13 & 0.02 \\
\hline 7 & 32.31 & 32.34 & 0.03 & 21 & 19.02 & 19.06 & 0.04 \\
\hline 8 & 32.26 & 32.29 & 0.03 & 22 & 36.57 & 36.59 & 0.02 \\
\hline 9 & 50.60 & 50.62 & 0.02 & 23 & 24.22 & 24.24 & 0.02 \\
\hline 10 & 36.99 & 37.02 & 0.03 & 24 & 39.80 & 39.83 & 0.03 \\
\hline 11 & 21.45 & 21.48 & 0.03 & 25 & 28.29 & 28.32 & 0.03 \\
\hline 12 & 40.12 & 40.15 & 0.03 & 26 & 22.74 & 22.78 & 0.04 \\
\hline 13 & 42.60 & 42.63 & 0.03 & 27 & 22.99 & 23.03 & 0.04 \\
\hline 14 & 57.00 & 57.04 & 0.04 & & & & \\
\hline
\end{tabular}

atom of the carboxyl group of the terminal residue of glucuronic acid (GlcUA") in the disaccharide fragment GC by -0.16 ppm compared to individual GC (Fig. 1). A smaller effect was also noted on the neighboring $\mathrm{C}-5^{\prime \prime}$ atom $(\Delta \delta=-0.08 \mathrm{ppm})$.

In addition, it is noted $\Delta \delta$ (up to 0.05 ppm) for a number of GC aglycone and
Chol C-atoms (Tables 1 and 2). The greatest effects were found for some $\mathrm{C}$-atoms in the $\mathrm{B}-\mathrm{E}$ rings of $\mathrm{GC}$, in the $\mathrm{B}-\mathrm{D}$ rings, and side chain of Chol, as well as all methyl groups of Chol. These data may indicate about hydrophobic interactions between the aglycone part of GC and Chol (Fig. 1).

\section{Conclusions}

The results of this work confirm the molecular complexation between GC and Chol. The interaction is accompanied by bathochromic shift and a hyperchromic effect. The formation of an intermolecular hydrogen bond between $\mathrm{OH}$ group at C-3 of $\mathrm{Chol}$ and $\mathrm{C}=\mathrm{O}$ group of terminal glucu-

ronic acid residue in the carbohydrate part of $\mathrm{GC}\left(\mathrm{C}^{3}-\mathrm{O}-\mathrm{H} . . \mathrm{O}=\mathrm{C}^{6^{\prime \prime}}\right)$ and hydrophobic contacts were confirmed by ${ }^{13} \mathrm{C}$ NMR and ATR FT-IR spectroscopy. The results of this work can be used to study of mechanisms of biological activity of GA, GC and other saponins. 


\section{Acknowledgements}

This work was carried out in the frame of an internal grant of Sevastopol State University (identifier 30/06-31).

\section{References}

1. Hostettmann K, Marston A. Saponins. Cambrige: Cambrige University Press; 1995. 548 p.

2. Tolstikov GA, Baltina LA, Grankina VP, Kondratenko RM, Tolstikova TG. Solodka: Bioraznoobrazie, Khimiya, Primenenie v Medicine [Licorice: Biodiversity, Chemistry, and Application in Medicine]. Novosibirsk: Geo; 2007. 311 p. Russian.

3. Asl MN, Hosseinzadeh H. Review of pharmacological effects of Glycyrrhiza sp. and its bioactive compounds. Phytother Res. 2008;22(6):709-24.

doi:10.1002/ptr.2362

4. Pavlova SI, Uteshev BS, Sergeev AV. Licorice root: possible mechanisms of antitoxicant, anticarcinogen, and antitumor properties (a review). Pharm Chem J. 2003;37(6):314-7. doi:10.1023/A:1026005931751

5. Sidhu GS, Oakenfull DG. A mechanism for the hypocholesterolaemic activity of saponins. Brit J Nutrit. 1986;55(3):643-9.

doi:10.1079/BJN19860070

6. Lorent JH, Quetin-Leclercq J, Mingeot-Leclercq MP. The amphiphilic nature of saponins and their effects on artificial and biological membranes and potential consequences for red blood and cancer cells. Org Biomol Chem. 2014;12(44):8803-22. doi:10.1039/c4ob01652a

7. Popov AM. Mechanisms of biological activity of ginsenosides: comparison with holothurian glycosides. Vestnik DVO RAN. 2006;6:92-104.

8. Selyutina OYu, Polyakov NE, Korneev DV, Zaitsev BN. Influence of glycyrrhizin on permeability and elasticity of cell membrane: perspectives for drugs delivery. Drug Deliv. 2016;23(3):858-65.

doi:10.3109/10717544.2014.919544

9. Wojciechowski K, Orczyk M, Gutberlet T, Geue T. Complexation of phospholipids and cholesterol by triterpenic saponins in bulk and in monolayers. Biochim Biophys Acta Biomembr. 2016;1858(2):363-73.

doi:10.1016/j.bbamem.2015.12.001

10. Yakovishin LA, Grishkovets V.I. Ivy and licorice triterpene glycosides: promising molecular containers for some drugs and biomolecules. Stud Nat Prod Chem. 2018;55:351-83. doi:10.1016/B978-0-444-64068-0.00011-5

11. Li S, Purdy WC. Cyclodextrins and their applications in analytical chemistry. Chem Rev. 1992;92(6):1457-70.

doi:10.1021/cr00014a009

12. Yakovishin LA, Grishkovets VI. Molecular complexes of ivy triterpene glycosides with cholesterol. Khimiya Rastitel'nogo Syr'ya. 2018;4:133-40.

doi:10.14258/jcprm.2018043607 